\title{
Izobraževanje odraslih za aktivno državljanstvo - nujnost ali utopija?
}

Andragoški center Slovenije je letos med Tednom useživljenjskega učenja že tretjič organiziral andragoški kolokvij, namenjen srečanju raziskovalcev, teoretikov in praktikov, ki se tako ali drugače ukvarjajo $z$ vprašanji, pomembnimi za izobraževanje odraslih. Kolokvij je namenjen premisleku o različnih teorijah, konceptih in praksah v izobraževanju odraslih, pri čemer se nam zdi posebej dragoceno, če o tem ne razpravljamo samo andragogi, temveč se nam pri tem pridružijo tudi pedagogi, psihologi, sociologi in drugi, ki z vidika svojih strok primerjajo svoje poglede $z$ našimi, načenjajo dileme, ki jih morda nismo zaznali, ali pa nam pomagajo iskati strokovne rešitve. Seveda pa je to predusem tudi odlična priložnost, da predstavimo svoja dognanja. Kolokvij načenja torej andragoška vprašanja in z njimi združuje različne stroke. Želimo si, da bi primerjal različne, tudi pousem diametralne poglede, razvijal kritični dialog in ponujal različne poti. Tako bogatimo svoje delo in verjamemo, da pripomoremo b kakovosti teoretičnega ali praktičnega dela drugih strokovnjakov.

Druga značilnost andragoškega kolokvija je, da za osrednjo temo izbiramo vprašanja, ki so $v$ določenem trenutku posebej zanimiva za razvoj andragogike, ali pa taka, ki sicer niso $v$ ospredju družbene pozornosti, so pa po našem mnenju pomembna z vidika uveljavljanja pravic odraslih do izobraževanja. Prav taka je bila tudi letošnja tema, ki smo jo naslovili Izobraževanje za aktivno državlianstvo - nujnost ali utopija? Gre za temo, ki je že nekaj časa na robu raziskovalnega dela, izobraževalne politike in tudi prakse.
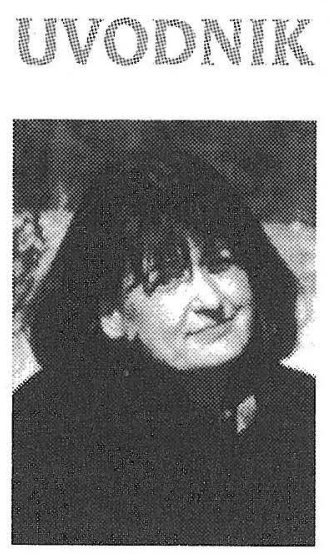

Sonja Klemencič

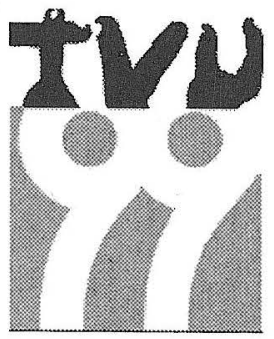

$V$ stroki namreč že kako desetletje opažamo, da $v$ Sloveniji $v$ nasprotju $z$ državami $z$ dališo demokratično tradicijo izobraževanje odraslih skoraj ne zajema izobraževanja, ki bi bilo namenjeno usposabljanju posameznika za aktivno družbeno sodelovanje in izrabljanje vseh možnosti, ki jih ponuja politični sistem pluralne demokracije. Ta pojav smo $v$ začetku 90. let razlagali kot normalno odzivanje na razmere, ki smo jim bili priča v prejšnjem političnem sistemu, zlasti v poznih 60. in 70. letih, ko je bilo usebinsko zelo osiromašeno, zato pa toliko bolj vsiljivo družbeno-politično izobraževanje eno izmed najrazvitejših področij izobraževanja odraslih. Ni šlo samo za svobodo izobraževanja, marsikdaj smo bili $k$ tourstne$m u$ "izobraževanju « preprosto prisiljeni. Nove družbeno-politične razmere $v 90$. letih so razumliivo pometle tourstno izobraževanje na smetišče zgodovine. Žal pa niti siroka niti praksa še nista (bili) sposobni premisleka, $v$ čem je bila zmota in pomota tega izobraževanja ter kaj je tisto, kar bi morali preoblikovati in razvijati naprej. Zadnje raziskave, ki smo jih opravili na Andragoškem centru Slovenije, namenjene pripravam dolgoročnega nacionalnega programa za izobraževanje odraslih, $\mathrm{ka}$ žejo, da je izobraževanja odraslih za aktivno državljanstvo (ali izobraževanja za demokracijo, državljansko izobraževanje ipd.) izredno malo. O tem drugače govorijo tudi stroke, $k i$ se ukvarjajo $z$ družbenimi gibanji, s sociološkimi pojavi ipd. Prav v zadnjem času mnogi strokounjaki opozarjajo na morebitne posledice tega, da je civilno gibanje, ki je imelo $v 80$. letih v Sloveniji izredno pomembno vlogo pri spreminjanju ekonomskega in političnega sistema, skoraj zamrlo, scimer pa so sicer legi- 


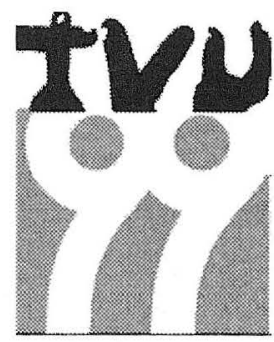

timne veje oblasti izgubile pomemben civilni nadzor.

Šele v zadnjem času so se v zvezi z izobraževanjem začela ponovno poudarjati vprašanja $d r$ žavljanske vzgoje, pa še to le v zvezi z osnovnošolskim izobraževanjem. Menimo pa, da je vprašanje izobraževanja za demokracijo še posebej pomembno tudi $v$ izobraževanju odraslih, saj novi ekonomski in politični sistem posamezniku sicer ponuja veliko svobode, izbire in možnosti, s tem pa tudi nujnost, da zna to svobodo uveljaviti, da pozna različne možnosti in zna pravilno izbirati zase. To ni samo slovenski problem, je tudi vprašanje nadalinjega razvoja evropske in svetovne demokracije. Zato ni čudno, da poročilo evropske komisije iz leta 1997 z naslovom Učenje za dejavno državljanstvo poudarja, da je to eden izmed ključnih izzivov razvoja $v$ naslednjih letih. Poročilo opozarja, da posameznikova pravica do družbenega sodelovanja še ne zagotavlja, da bodo ljudje dejansko delovali $v$ praksi, in tudi ne pomeni, da so »opremljeni « z vsem, kar potrebujejo za tako delovanje.

S kolokvijem smo želeli spodbuditi prav to, da bi se skupaj vprašali, ali je izobraževanje odraslih za aktivno državljanstvo splob potrebno in, če je, kakšno naj bi bilo. V razpravi se nismo mogli pousem izogniti sedanjim ekonomsko-političnim razmeram, kar je seveda povsem razumlivo, saj je demokracija kot vrednota skozi vso zgodovino odsevala čas, $v$ katerega je bila nokvirjena. Prav tako so bile opazne razlike med pojmovanjem aktivnega državljanstva: nekateri razpravljalci so imeli bolj $v$ mislih koncept meščanske demokracije, ki opredeliuje temeljni vzvod demokratičnosti $v$ splošni volilni pravici in skupnem soodločanju v ljudskih predstavniških organih, drugi pa so izhajali iz koncepta tako imenovane participativne demokracije, ki predpostavlja še mnoge druge pojavne oblike, poti in možnosti, da celovito uveljavliamo svojo pravico do soodločanja, sodelovanja, odgovornostiza lastno in skupno življenje. Temeljna razprava pa se je seveda ukvarjala z vprašanjem izobraževanja. Spraševali smo se, ali se je aktivnega sodelovanja $v$ družbenem življenju mogoče naučiti in, če se je mogoče, kako, s kakšnimi vsebinami. Nekateri so se spraševali, $k d o b i$ moral razvijati tako izobraževanje, skoraj vsi razpravljalci so tako ali drugače razmišljali o razmerju med vzgojo in izobraževanjem za demokracijo. Kar nekaj razpravljalcev je opozorilo na povezanost splošne izobraženosti in sposobnosti za soodločanje v skupnosti. Tako smo nekako spet naleteli na vprašanja, o katerih smo razmišljali na lanskem drugem andragoškem kolokviju, ko smo se pogovarjali o socialni izključenosti in izobraževanju. Ali, kot meni Roseanne Benn z univerze $v$ Exeterju (Velika Britanija), ki je na kolokviju sodelovala s pisnim prispevkom, prenizka izobrazba vodi $k$ socialni izključenosti, ta pa je vzrok nesposobnosti za aktivno vplivanje na življenje $v$ skupnosti.

Na kolokviju nismo iskali ene same resnice ali pravilnih odgovorov. Zato so pred vami prav vsi prispevki referentov in razpravljalcev, bolj teoretično ali bolj praktično usmerjeni, taki, ki skušajo čimbolj celovito obravnavati izbrano temo, in taki, ki se posvečajo le manj pomembnim, posebnim vprašanjem. Berite jih $z$ odprtim srcem, pustite, da v vas vzbudijo strinjanje ali dvom. Organizatorji kolokvija bomo veseli, če smo tako vsaj malo pripomogli, da bi se o izobraževanju odraslih za aktivno državljanstvo odslej večkrat pogovarjali in tako tudi delovali.

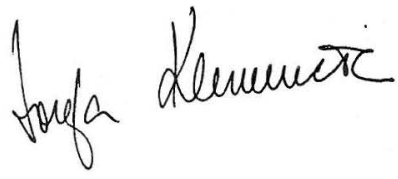

